\title{
State Aid to enterprises in Croatia in 2001
}

Kesner-Škreb, Marina; Pleše, Ivana; Mikić, Mia

Source / Izvornik: Occasional Paper Series, 2003, 7, 1 - 17

Journal article, Published version

Rad u časopisu, Objavljena verzija rada (izdavačev PDF)

https://doi.org/10.3326/ops.18

Permanent link / Trajna poveznica: https://urn.nsk.hr/urn:nbn:hr:242:713273

Rights / Prava: Attribution-NonCommercial-NoDerivatives 4.0 International/ImenovanjeNekomercijalno-Bez prerada 4.0 međunarodna

Download date / Datum preuzimanja: 2023-04-26

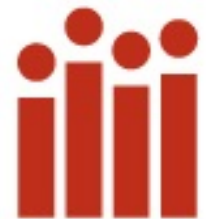

Repository / Repozitorij:

Institute of Public Finance Repository

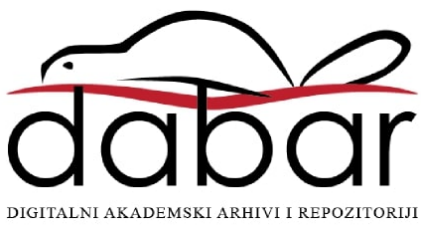


STATE AID TO ENTERPRISES IN CROATIA IN 2001

Marina Kesner-Škreb, Ivana Pleše and Mia Mikić

Occasional Paper No.18

October 2003 


\title{
STATE AID TO ENTERPRISES IN CROATIA IN 2001 ${ }^{1}$
}

\begin{abstract}
State aid to enterprises is a form of government intervention. Under the Stabilization and Association Agreement with the EU Croatia has accepted certain obligations concerning the allocation and control of state aid. The objective of this research project was to assess the size and structure of state aid in Croatia and to compare it with the aid provided by Member States (and candidate countries). In 2001, State aid in Croatia represented $5.25 \%$ of GDP, and was five times the size of aid in the EU. At the same time, Croatia provided a much stronger support to certain economic sectors than the EU, particularly agriculture, transport, tourism and shipbuilding. On the other hand, the aid for research and development, small and medium-size enterprises or environmental protection, which are in the EU the main recipients of the so-called 'horizontal aid', the aid used by all enterprises and sectors and not only selected ones, was much smaller. It should therefore be expected that Croatia would have to reduce the volume of its state aid in the course of its adjustment to the EU, and gradually redirect the aid from selected sectors to all enterprises, through horizontal forms of aid. At the same time, it should improve its system of allocation and control of state aid.
\end{abstract}

JEL Classification: H40, H70, F33

Key words: state aid, state intervention, Croatia, European Union.

\footnotetext{
${ }^{1}$ This research is a follow-up on the study conducted during 2002 and published in: Kesner-Škreb, Marina and Mikić, Mia, 2002: "State Aid in European Union and Croatia", "Croatian Accession to the European union - economic and legal challenges", edited by Ott, Katarina, Institute of Public Finance and Friedrich Ebert Foundation, Zagreb.

We wish to express our gratitude to Sanja Mađarević-Šujster and Katarina Ott for providing insightful comments on earlier drafts. We would also like to thank Branka Ivančić, Stanko Zorica and Vanja Goldberger for the assistance provided in collecting the necessary data. Our special thanks to Lea Lekočević and Ervina Blažić of the Commission for State Aid Control, Ministry of Finance of the Republic of Slovenia. Without their generous help it would have been almost impossible to produce this paper. We would also like to extend our appreciation to the Institute of Public Finance, which recognized the importance of this study and provided the funding.

We emphasize that the statements given in this paper represent the authors' personal views, which are by no means binding on the institutions they work with. This article is published in Croatian in the journal "Financijska teorija $\mathrm{i}$ praksa", 27(3), 2003, pp 287-330, and is downloadable from http://www.ijf.hr/financijska_praksa/2003/3.htm.
} 


\section{Introduction}

Control of state aid constitutes an important part of the Stabilization and Association Agreement between the Republic of Croatia and the European Communities and their Member States (SAA), included in Title $\mathrm{VI}$, which regulates the adjustment and implementation of legislation and rules of market competition. Also in this area Croatia has to ensure gradual adjustment of its legislation with the Community acquis. Pursuant to Article 70 of the SAA Croatia is required to establish an independent agency authorized to allocate and supervise state aid. The final objective of these measures will be to review the state aid system and to make the necessary changes in the volume and structure of state aid. In so far we considered it necessary to give an overview of state aid in Croatia in accordance with the EU methodology. At the beginning of our research we had most of the final data for 2001 but not for other years, so we decided to limit our study only to 2001 in order to provide an accurate picture of state aid. Thus, the paper presents aggregate data on the size of state aid and its objectives for the selected year. Based on the comparison between Croatia and the EU, this study indicates the direction in which state aid should develop in future, concerning both its size and structure. It should be noted that we do not analyze the problems of particular industries, economic sectors or regions as they are beyond the scope of our study.

In addition to this introduction, the study consists of four parts. The second part provides a short summary of state aid as a form of state intervention. The third part gives an overview of rules on the EU state aid system, and the basic developments in the volume and the objectives of state aid in Member States and candidate countries. The EU requirements concerning state aid that Croatia has to satisfy are dealt with in the fourth part, while the fifth, fundamental part of this study presents the methods of assessing state aid in the EU, which were in this research also applied to Croatia. Finally, this part also outlines the results of state aid measurement for 2001 based on this methodology. The study concludes with a presentation of the main findings and recommendations for economic policy makers.

\section{State Intervention and State Aid}

Many countries implement various measures of state intervention providing substantial funds to financially support certain enterprises or industries. The aid is usually allocated to companies, which are in financial difficulties but also to businesses, which are expected to be the agents of future economic development. Thus, for example, in 1999, the aid allocated by the EU Member States to their companies stood at EUR 86 billion (Commission of the EC, 2003). In the same year, another EUR 63 billion flowed into these economies from the funds at the EU level ${ }^{2}$ (Commission of the EC, 2001:150). This means that the financial aid received by EU companies from both national sources and funds at the EU level amounts to around EUR 150 billion annually.

The fact that the absolute amounts granted are really substantial raises a number of questions: What is in fact state aid? Should all companies be supported, or support should be provided only to the selected ones? What are the consequences of granting aid to companies? Should state aid be monitored, by

\footnotetext{
${ }^{2}$ European Social Fund, European Agricultural Guidance and Guarantee Fund, European Regional Development Fund and Cohesion Fund.
} 
whom and how? The answers to these questions, which start with a clear definition of state aid, are given below and are mainly based on the definitions and methodologies applied within the EU.

\subsection{Definition of State Aid}

Governments use various measures to intervene in the economy and provide help to companies, and state aid is just one of the three forms of state intervention. In fact, state intervention in the markets may take the following forms: (i) financial assistance, (ii) regulation, and (iii) direct government investment in goods or services (OECD, 2001). The first form of state intervention, i.e. financial assistance to companies (direct or indirect) is known as state aid. It can be granted through a direct transfer of budgetary funds, or, indirectly, through subsidized loans, state guarantees, tax allowances, etc. Consequently, state aid represents just one of the three possible forms of state intervention, i.e. direct or indirect financial assistance to companies. The objective of aid as a form of state intervention is to promote certain economic sectors, regions or activities. According to the definition applied within the EU, state aid comprises funds granted by a particular country from its own sources to selected companies or industries, thereby influencing the trade between Member States and distorting or threatening to distort competition. State aid distorts competition because it discriminates between firms that operate in the market without receiving state aid and those which receive it (Commission of the EC, 2003). What does it mean "to distort competition"? According to the market criterion, an aid distorts competition if no participant in the market wishes to invest the same amount under the same terms in a company supported by the state (Lavadas and Mendrinou, 1999). That means that through its grants the state diverts investments into those enterprises and industries in which private investors do not (wish to) invest (Adams and Klein, 1985; Schultze, 1986; Krugman, 1986).

According to the above EU definition, state aid comprises a large number of measures, and can be granted in the form of direct subsidies from the budget $^{3}$, soft loans, state guarantees, tax exemptions, reduction in social security contributions, direct government capital investment, etc.

\subsection{Why Does the State Support Companies?}

All governments provide some sort of financial assistance to their companies. There are many different reasons for granting state aid (OECD, 2001:7), e.g.:

- to promote economic activity in a certain area,

- to provide services not provided for by the market (for example, transport of goods and passengers to outlying areas or islands),

- to alleviate recession in certain industries (e.g. shipbuilding),

- to support the industries, which are strongly exposed to the influence of nature's forces (e.g. agriculture),

- to maintain the level of producers' income,

- to correct other 'market failures' (e.g. research and development, environmental protection),

- to promote employment (particularly of youth, women and the handicapped), and

\footnotetext{
${ }^{3}$ The terms 'grant' and 'state aid' are often considered as synonyms. In this paper we will apply the EU definition according to which grant is just a form of state aid, i.e. a direct transfer from the budget.
} 
- to increase the market share of own enterprises at the expense of enterprises from other countries.

Financial aid to enterprises may increase public welfare, but can also distort competition and therefore decrease welfare. The latter occurs when aids are granted to less efficient enterprises producing lowquality products at high costs. On the other hand, public welfare improves and the economy grows if state aid is aimed at correcting market failures. Consequently, "bad" aid distorts the market by favoring one company over another and thus decreasing public welfare, while "good" aid corrects market failures and so contributes to the growth of public welfare (Neil, 1990). However, it should be emphasized that an aid results in increased welfare only if the efficiency improvement achieved on account of the state aid exceeds the direct and indirect costs of the application of such aid (Nicolaides and Bilal, 1999).

There is abundant literature about whether, when and how should the state provide aid to companies or entire industries. Most authors conclude that state aid can only be justified if it is aimed at correcting a market failure (Commission of the EC, 2003). The usual market failures include externalities, public good, economies of scale and asymmetric information (Kesner-Škreb, 1994). It is therefore considered that the state should intervene to correct these market failures, for example, by subsidizing education and science, investing in environmental protection, providing information about investment opportunities to small and medium-size enterprises etc. (see Table 1).

Table 1 Market Failures and Their Correction

\begin{tabular}{|c|c|c|}
\hline Name of the market failure & Example of a market failure & $\begin{array}{l}\text { The most frequent form of } \\
\text { state aid }\end{array}$ \\
\hline Public good & $\begin{array}{l}\text { Lighthouses, street lighting, } \\
\text { public radio and television }\end{array}$ & $\begin{array}{l}\text { The service is provided directly } \\
\text { by the state. }\end{array}$ \\
\hline Merit good & $\begin{array}{l}\text { Vaccination campaigns, primary } \\
\text { education }\end{array}$ & Subsidies or full financing \\
\hline Economies of scale & $\begin{array}{l}\text { Monopolistic and oligopolistic } \\
\text { markets }\end{array}$ & $\begin{array}{l}\text { Assistance to companies } \\
\text { entering the market }\end{array}$ \\
\hline $\begin{array}{l}\text { Positive externalities } \\
\text { Negative externalities }\end{array}$ & $\begin{array}{l}\text { Research and development, } \\
\text { Pollution }\end{array}$ & $\begin{array}{l}\text { Subsidies } \\
\text { Taxes, regulation }\end{array}$ \\
\hline $\begin{array}{l}\text { Incomplete or asymmetric } \\
\text { information }\end{array}$ & $\begin{array}{l}\text { Small and medium-size } \\
\text { enterprises have limited access } \\
\text { to credit }\end{array}$ & $\begin{array}{l}\text { Subsidized interest, guarantees, } \\
\text { information centers }\end{array}$ \\
\hline Inflexibility of labor markets & Minimum wage & $\begin{array}{l}\text { Reduction in social security } \\
\text { contribution, employment } \\
\text { subsidies }\end{array}$ \\
\hline Reduced factor mobility & $\begin{array}{l}\text { Difficulty to move labor and } \\
\text { capital to underdeveloped areas }\end{array}$ & $\begin{array}{l}\text { Improving the quality of } \\
\text { infrastructure }\end{array}$ \\
\hline $\begin{array}{l}\text { Difficulties in adapting to } \\
\text { market changes }\end{array}$ & $\begin{array}{l}\text { Company or sector that needs } \\
\text { restructuring }\end{array}$ & Assistance in market exit \\
\hline Foreign subsidies & $\begin{array}{l}\text { Supporting domestic industry as } \\
\text { a reaction to subsidized foreign } \\
\text { products }\end{array}$ & $\begin{array}{l}\text { Subsidies, negotiations with the } \\
\text { WTO }\end{array}$ \\
\hline
\end{tabular}

Source: European Commission, 1999: 25.

However, the implementation of state aid cannot be justified only by market failures. It is also necessary to prove that public sector (i.e. the state) can resolve the established problem more successfully than the private sector (markets) (Sandmo, 2002). It is very hard to determine the size, implementation period and form of state aid, as the government's decision relies on incomplete information on the state of the 
economy. Thus, for example, each form of state aid like subsidies, tax benefits, soft loans etc., has its advantages and drawbacks, and it may have a completely different impact on the economic efficiency of a selected industry, the economy as a whole and public welfare. Prior to the implementation of a certain form of state aid, all benefits and costs (both direct and indirect) connected with it should be considered. This is because the very existence of a market failure does not necessarily justify the implementation of corrective measures: the cure may be worse than the disease (Martin and Valbonesi, 1999).

\subsection{Effects of State Aid}

The conventional state intervention usually implies the government's selection of industries or companies, which need assistance. These are future "winners", i.e. industries and companies which are expected to achieve high growth rates, or past and /or current "losers", i.e. industries and companies in difficulties, which need state aid for the survival in the market. The implementation of such form of state intervention requires great analytical skill from the government in order to establish, better than the market itself, the appropriate economic structure, to select potential winners among industries and companies, to decide which "losers" are worth saving and to undertake measures through which all this should be implemented.

However, experience shows that such traditional approach is inefficient and hardly results in restructuring and growth. The state has generally proved to be inefficient in many ways: it could not recognize 'winners' neither could it determine the right moment to stop providing assistance, i.e. the moment when the company becomes capable of independent operation. Moreover, its measures, often inappropriate, resulted in numerous distortions, which further reduced economic efficiency ${ }^{4}$. Under the pressure from various interest groups the state aid network became more complicated, while state administration became liable to corruption. Once the state intervention is established, the state may fall under the influence of different interest groups, which actively lobby to retain the state aid. In addition, there are always new 'candidates' who could make good use of state aid. For why subsidize agriculture and not tourism or food industry, which are closely related to agriculture? Owing to the influence of interest groups, it is difficult to eliminate a provision of state aid once it has been granted. Indeed, new forms of aid get to be introduced making difficult break this vicious circle (Kesner-Škreb and Mikić, 2002).

Moreover, state aid results in unfair competition between subsidized and non-subsidized companies. More specifically, owing to lower prices charged by subsidized companies, due to them receiving aid and not because they were more productive or innovative, non-subsidized companies whose products were more expensive, even if of better quality, were forced out of the market. Parallel to this, the pressure of growing state aid on the state budget becomes stronger, leading up to increased taxes and threatening fiscal stability. As state aid is actually financed from tax revenues, its cost is borne by all taxpayers. Thus, despite the fact that consumers paid lower prices for subsidized products, in the end they have to pay the full non-subsidized prices through higher taxes.

In many cases state aid reduces welfare and weakens the motivation of companies to improve their efficiency. Similarly, state aid can create problems in trade between the trading partners and in the EU between the Member States. Specifically, subsidizing domestic production by state aid creates a basis 
for the implementation of predatory policy and appropriation of international market shares. The affected country may react to such policy by taking retaliatory measures under the motto: "You help your industry, I'll help mine." Some countries are very often the victims of such 'retaliation policy' where state aid is granted in reaction to foreign subsidies (Nicolaides and Bilal, 1999). Therefore the EU has established a system of state aid control, which is supposed to reduce such inefficiencies.

\subsection{State Aid Control}

The state aid control in the EU is a unique example of control at the supranational level. The main reasons for the state aid control are distortion of competition in the market, prevention of resource allocation to most efficient industries and jeopardizing the trade between the Member States. The system of control rests on an agreed set of rules, which are based on the Treaty Establishing the European Community (the Treaty), and is aimed at reducing the negative effects of each particular state aid on competition (Commission of the EC, 2001).

Over time, the system of state aid control in the EU has become very sophisticated. However, the EU makes great efforts to reform and modernize its state aid control procedures and focuses these efforts and funds on the cases, which represent the most serious threat to competition. For this reason, the European Commission has carried out a close internal audit, in order to establish the segments of the state aid control procedures, which need to be simplified and shortened.

Apart from the EU system of state aid control, which is a unique system of supranational control, the WTO has its own rules on subsidies under the Agreement on Subsidies and Countervailing Measures which mainly cover the subsidies affecting the level playing field and terms of trade in goods.

However, in addition to the supranational control systems, a more effective control and transparency of state aid is also required at the national level. This would reduce the pressures of certain interest groups on keeping current and introducing new types of aid. Moreover, this would result in a more effective control of government spending, while the resources could be used for more efficient purposes.

\section{State Aid in the European Union}

\subsection{Rules on the EU State Aid System}

The point of departure of the state aid policy is laid down in the Treaty Establishing the European Coal and Steel Community (ECSC) of 1951 and the Treaty of Rome Establishing the European Economic Community of 1957. Although these documents provided legal framework for state aid, it is worth mentioning that, for a longer time, no explicit guidelines have been adopted about these issues, neither have any agreements on state aid been reached between Member States. By the late 1980s it was increasingly felt that an uncontrolled growth of state aid might present a serious threat to the competition of the integrated market to be established. The fact was that state aid, by giving selected companies or products favoured treatment to the detriment of other companies or products, disrupts normal competitive forces in a most serious yay. This risk of distortion of competition motivated the European Commission (the Commission), as well as the individual Member States, to adopt a more rigid state aid

\footnotetext{
${ }^{4}$ In literature, these disadvantages are often referred to as state failures.
} 
policy. The rules regulating these issues have been created and developed gradually through the adoption of various guidelines, instructions, court rulings, etc, and are still being supplemented.

The current legal basis for the policy on state aid within the EU is outlined in Articles 87-88 of the Treaty Establishing the European Community (the Treaty) ${ }^{5}$. The current system of rules outlined in the stated articles is further explained in this chapter.

As already mentioned, state aid is a form of state intervention used to promote a certain company or economic activity at the detriment of others. The rules on state aid constitute a part of the legislation of the European Commission covering market competition. Articles 85-94 cover the whole area of competition, where Articles 87-88 provide general regulations on state aid.

The general regulations rely on the principle that state aid is prohibited unless certain condition allowing the exception from this general rule are satisfied. The general ban on state aid arises from the legislator's conviction that uncontrolled favoring of selected companies or economic sectors in individual Member States would jeopardize the operation of the single market. Therefore, the general ban was motivated by the need to control subsidies in certain Member States (Kobia, 1996:3). As concerns the supranational control of state aid, the EU is unique, as the European Commission holds a monopoly on approving aid in individual Member States. One should also distinguish between the state aid granted by Member States (which is regulated by the above mentioned Treaty) and the aid granted at the EU level from structural or regional funds. The control of aid from these funds is not regulated by Articles $87-88$ of the Treaty.

The point of departure of EU state aid policy is laid down in Article 87(1) of the Treaty. It provides that state aid is in principle incompatible with the common market. Under Article 88, the Commission is given the task to control state aid. This article also requires Member States to notify the Commission in advance of any plan to grant state aid.

\section{Box 1. Article 87(1) of the Treaty}

"... any aid granted by a Member State or through State resources in any form whatsoever which distorts or threatens to distort competition by favoring certain undertakings or the production of certain goods shall, insofar as it affects trade between Member States, be incompatible with the common market."

It follows that the European Commission does not control all forms of state aid, but its rules only apply to those measures that satisfy all the criteria laid down in Article 87(1) ${ }^{6}$ :

1. Transfer of State resources. State aid rules cover only transfers of State resources (national and regional budgets, state-owned banks and funds, etc.). However, the aid is not necessarily granted by the State itself, but also by private or public bodies appointed by the State.

2. Economic advantage. The aid should constitute an economic advantage that the recipient would not have in his/her normal course of business.

\footnotetext{
${ }^{5}$ The English abbreviation for the Treaty Establishing the European Community is 'EC Treaty'. It relates to commercial agreements, which have undergone several amendments. The consolidated version of the Treaty, which has been in force since 1 February 2003, is available on the Internet at: http://europa.eu.int/eurlex/pri/en/oj/dat/2002/c 325/c 32520021224en00010184.pdf.

${ }^{6}$ This presentation relies on the information from "Vademecum Community Rules on State Aid", (2002) (hereinafter: Vademecum).
} 
3. Selectivity. State aid affects the balance between companies receiving assistance and their competitors. Selectivity is what makes state aid different from general economic measures, i.e. those which apply to all firms in all economic sectors.

4. Effect on trade within the EU. Aid has adverse effects on trade between Member States, i.e. it distorts or threatens to distort competition.

Aid classified as de minimis aid (for more detail please refer to Box 2) does not fall within the scope of this study. State aid to a company, which amounts to less than EUR 100,000 over a three-year period is considered too low to have any significant effect on competition and trade, and therefore falls outside the scope of Article 87(1). However, Member States are required to monitor closely state aid in order to prevent cumulation of aid to exceed the stated cash limit, in which case even small amounts of aid shall be subject to Article 87(1).

\section{Box 2. De minimis rule}

Reference:

«Commission Regulation (EC) No 69/2001 of 12 January 2001 on the application of Articles 87 and 88 of the EC Treaty to de minimis aid» (Official Journal No L 10,13.1.2002, p.30).

Scope:

Small amounts of aid ("de minimis aid") which do not constitute state aid in the sense of Article 87(1) and which are therefore not subject to the notification requirement. This rule does not apply to coal, steel or transport, as well as to production, processing and marketing of agricultural and fisheries products as referred to in Annex I to the Treaty.

\section{Concept:}

The de minimis rule sets a threshold figure for aid below which Article $87(1)$ can be said not to apply, so that the measure need no longer be notified in advance to the Commission. The rule is based on the assumption that, in the vast majority of cases, small amounts of aid do not have an effect on trade and competition between Member States.

Criteria:

- the amount of aid may not exceed EUR 100,000 over any three-year period;

- this ceiling applies to the total of all public assistance considered to be de minimis aid and it does not affect the possibility for a recipient to obtain state aid on the basis of other criteria;

- the ceiling applies to aid of all kinds, irrespective of the form it takes or the objective pursued. The only exception from the de minimis rule is export aid.

\section{Cumulation:}

The above ceiling applies to the total amount of de minimis aid granted to a single company. The Member State is responsible for establishing the instruments needed to ensure an effective control of the respect of the de minimis cumulation ceiling. This can be done in two ways:

- by setting up a central register of de minimis aid

- by obtaining from the enterprise concerned full information about other de minimis aid received during the previous three years. Under all conditions, the Member State remains responsible for ensuring the respect of the cumulation ceiling.

Source: Vademecum, 2002:13.

Pursuant to Article 87(1), aid which satisfies all the above-mentioned criteria is in principle incompatible with the common market. However, the incompatibility rule does not imply a total ban. Article $87(1)$ and 
(2) specify a number of cases when state aid may be compatible provided that it does not disturb the common market. The long list of such state measures indicates that both the individual countries and the $\mathrm{EU}$ as a whole are given freedom to design their own state aid systems. According to Article 87(2), the following aid categories are compatible with the common market:

a) aid having a social character, granted to individual consumers, provided that such aid is granted without discrimination related to the origin of the products concerned;

b) aid to make good the damage caused by natural disasters or exceptional occurrences;

c) aid granted to the economy of certain areas of the Federal Republic of Germany affected by the division of Germany, insofar as such aid is required in order to compensate for the economic disadvantages caused by that division.

Article 87(3) provides for even more possibilities of intervention and specifies those categories of aid that are considered as compatible with the common market, i.e.:

a) aid to promote the economic development of areas where the standard of living is abnormally low or where there is serious underemployment;

b) aid to promote the execution of an important project of common European interest or to remedy a serious disturbance in the economy of a Member State;

c) aid to facilitate the development of certain economic activities or of certain economic areas, where such aid does not adversely affect trading conditions to an extent contrary to the common interest;

d) aid to promote culture and heritage conservation where such aid does not affect trading conditions and competition in the Community to an extent that is contrary to the common interest;

e) such other categories of aid as may be specified by decision of the Council acting by a qualified majority on a proposal from the Commission.

Given the number and diversity of compatible categories of aid, its is clear that the main objective of the state aid control at the EU level is not the abolishment of or ban on state aid, but the prevention of unnecessary distortion of competition. This can be achieved by monitoring and regulation of aid, and by defining the terms under which Member States can allocate specific structural and/or regional aid.

The Commission has established a series of criteria and procedures for determining whether a certain form of state aid is compatible or not. They are based on the size and location of a company, type of industry, the objective of aid, etc. The Commission discloses these criteria in the form of communications, notices, frameworks, guidelines and letters to Member States.

Here we single out some features of aid that should be taken into account when considering the categories of aid covered by Article 87(3). According to the Guide compiled in Ireland (State Aid Unit, 2003: 12), the Commission has taken an openly hostile position on state aid that is:

- related to exports and is prohibited by the WTO rules ${ }^{7}$;

- contrary to the rules on the uniform organization of the EU agricultural market;

\footnotetext{
7 This relates to direct export subsidies, which are dependable on the volume of exports and are specifically forbidden by the WTO Agreement on Subsidies. However, aid to exporters, which is not dependable on the volume of exports, e.g. assistance for the exhibition at fairs, is not questionable.
} 
- used for covering current (operating) costs of launched projects, and is not related to the initial investment in a project. For example, for the period 2000-2006 no approval has been granted in Ireland for aid to cover such costs.

\subsection{Notification and Authorization Procedures}

The obligation to notify and supervise state aid is laid down in Article 88 of the Treaty. In order to avoid unnecessary disturbances in the functioning of the common market and distortion of competition, Member States are required to notify the Commission of any plans to grant or alter a state aid before putting it into effect (ex ante authorization). The Commission has the discretionary right to decide whether the proposed state aid complies with Article 87(1) and satisfies the exemption requirements laid down in Articles 87(2) and 87(3). Any aid granted by a Member State without a prior notification to and approval by the Commission shall be considered as unlawful aid and the Commission is obliged to order the recovery of such aid, in accordance with the effective regulations.

As early as 1998 , the Commission started to accelerate the state aid approval procedures. Thus, the above described procedure was simplified by adopting the so-called block exemption regulations, which enabled the Commission to declare certain categories of state aid compatible with the legislation, thus exempting them from the requirement of their prior notification by Member States and from the Commission's approval. As a result, three categories of state aid are exempt from the notification and approval procedures, i.e.:

- aid to small and medium-size enterprises;

- aid for training; and

- aid for employment.

The de minimis aids described in Box 2 are also exempt from the prior notification requirement.

In the case of aid for small and medium-size enterprises, training aid and aid for employment, Member States are required, instead an ex ante notification, to submit to the Commission a summary description of the aid within these categories not later than 20 working days following the implementation of the measure. In the case of de minimis aid, which is also included in this category, it is not even necessary to submit the summary ex post information.

\subsection{Amount and Structure of State Aid in Member States and EU Candidate Countries}

According to the latest available report on state aid (State Aid Scoreboard) in EU Member States (Commission of the EC, 2003), the control of state aid succeeded in reducing the total amount of aid and redirecting aid from selective to horizontal objectives ${ }^{8}$ which are of common interest. However, "although each individual grant of aid is awarded under conditions accepted by the Commission, and notwithstanding the positive effect that aid may have in other policy areas, the cumulative effect of some EUR 86 billion of state aid in 2001 was a considerable distortive effect on competition in the internal market" (Commission of the EC, 2003:8).

The following conclusions can be drawn from the figures presented in the reports on state aid (Commission of the EC, 2002 and 2003): 
- The total amount of aid decreased from EUR102 billion in 1997 to EUR 86 billion in 2001, i.e. from $1.3 \%$ of GDP to $0.99 \%$ of GDP;

- In 2001, aid for manufacturing, coal, financial services and agriculture decreased significantly, while the reverse trend was observed in aid for the railway sector and environmental protection;

- Although Germany and Italy made the largest contribution to the reduction in total state aid, by reducing their assistance to regions, they both remain among the countries with most generous state aid to companies. Thus, in 2001, Germany allocated the highest absolute amount of aid (EUR 23 billion), followed by France (EUR 16 billion) and Italy (EUR 12 billion). State aid declined in all EU Member States, except Great Britain, where total aid rose in 2001 due to an increase of aid for transport;

- There remain substantial differences between Member States concerning the use of state aid. Thus the smallest share of state aid in GDP was recorded in Great Britain $(0.66 \%)$ and the largest in Finland $(1.58 \%)^{9}$;

- The sectoral structure of state aid is very important for the quality of competition in the common market. In 2001, $46 \%$ of the overall amount of EU aid was granted for transport, primarily for railways. Manufacturing participated with $25 \%$, agriculture and fisheries with $15 \%$, coal with $7 \%$ and other aid with $7 \%$ in total aid;

- A similar unevenness, observed in the relative share of GDP of individual Member States, can be found in the sectoral structure of aid. Thus, the lowest amount of aid to agriculture and fisheries was allocated in Denmark and Germany (9\% of total aid), while the largest amount was allocated in Finland (65\%). Transport (railways) received more than $60 \%$ of total aid in Belgium, Luxembourg, the Netherlands and Great Britain, $17 \%$ in Finland and only $2 \%$ in Portugal. Germany and Spain still allocate a large share of total aid for coal (18\% and $22 \%$ respectively), while among other Member States only France and Great Britain support this sector (with $6 \%$ and $1 \%$ respectively of the total aid);

- A considerable growth was recorded in aid for horizontal objectives, which rose by $13 \%$ in the period 1998-2000 compared with the period 1996-1998. This favorable trend is noticeable in all Member States;

- In the period $1999-2001$, over $63 \%$ of the overall amount of aid for manufacturing was allocated through subsidies from the budget, which thus represented the most frequent form of state aid;

- In 2002, there were around 1000 cases of state aid registered by the Commission, of which $44 \%$ was intended for the manufacturing and service sectors, $38 \%$ for agriculture, $10 \%$ for fisheries and $8 \%$ for transport and power supply. Despite the obligation of Member States to notify aid to the Commission prior to its implementation, in $15 \%$ of all cases the authorization procedure was started by the Commission itself only after it had learned about the planned aid;

- Of the total number of final decisions of the Commission on the received notifications in the period 1999-2001, only $7 \%$ were negative.

\footnotetext{
${ }^{8}$ Horizontal state aid is the aid allocated to certain sectors. For more information, please refer to Chapter 5.1.

${ }^{9}$ Such a large share of state aid in GDP in Finland can be accounted for by large amounts of aid for agriculture (almost 65\%). Excluding the aid for agriculture, this ratio comes down to $0.29 \%$ of GDP in Finland compared with the EU average of $0.38 \%$.
} 
The EU objective agreed at the European Council's meetings in Stockholm (2001) and Barcelona (2002) is to increasingly allocate state aid for the correction of the established market failures. This means that state aid should be redirected to horizontal objectives common to all industries and activities such as research and development (R\&D), small and medium-size enterprises and environmental protection, without supporting specific sectors, which could distort competition much more seriously. In March 3003, the European Council in Brussels again called on the governments to "..further reduction in state aid and the redirection of aid to horizontal objectives. It also welcomed the Commission's intention to continue working to simplify and modernize state aid arrangements, focusing attention on the most distorting aid." (Commission of the EC, 2003).

It may also be useful to compare the levels of state aid granted by candidate countries, which are ahead of Croatia on state aid monitoring. In twelve candidate countries the amount of state aid granted reached almost EUR 5 billion in 2002. The most "generous" were Poland, Hungary, Czech Republic and Romania, which account for almost $85 \%$ of the total amount of aid (Commission of the EC, 2002a).

Table 2 Comparison of Basic Data on State Aid between EU Member States and Candidate Countries

\begin{tabular}{|l|c|c|}
\hline 2000 & EU 15 & CC 12 \\
\hline State aid (in bn EUR) & 70 & 1.3 \\
\hline State aid as \% of GDP & 0.8 & 105 \\
\hline State aid per capita (PPS/cap) & 185 & 46 \\
\hline $\begin{array}{l}\text { Share of state aid for } \\
\text { manufacturing (in total aid) }\end{array}$ & 35 & 51 \\
\hline $\begin{array}{l}\text { \% of aid for manufacturing in } \\
\text { the form of tax exemptions }\end{array}$ & 29 & 25 \\
\hline $\begin{array}{l}\text { \% of aid for the manufacturing } \\
\text { sector in the form of subsidies }\end{array}$ & 62 & 2 \\
\hline
\end{tabular}

Note: PPS purchasing power standard

Source: Commission of the EC, 2002a.

Note: Total amounts of state aid are reduced here by the aid to agriculture and fisheries. PPS is an acronym for 'purchasing power standards', i.e. a measure which observes the difference in price levels in individual countries. CC12 stands for the twelve candidate countries.

In general, the share of state aid in GDP in candidate countries is larger than that of EU Member States, reaching $1.3 \%$ of GDP on average (the EU average for 2000 was $0.8 \%$ ). The share of aid in Estonia is as low as $0.5 \%$, while in Hungary and Romania it stands at around $1.7 \%$.

Expressed in per capita amounts, the state aid in candidate countries is much below that in EU Member States. Even if we consider the differences in purchasing power per capita, the EU average is almost two times as high as the average for the candidate countries.

The sectoral structure of state aid suggests that candidate countries predominantly direct their aid to the manufacturing sector (46\% compared with the EU average of $35 \%$ ). Transport receives as little as $22 \%$ (EU average $46 \%$ ), and coal gets only $12 \%$ of total aid.

The differences among candidate countries are much more pronounced than among Member States, both with respect to the amounts and to the sectoral structure of state aid. In addition, while candidate 
countries allocate the largest portions of aid in the form of tax exemptions, Member States mostly grant direct subsidies from their budgets.

\section{The European Union's Position on the State Aid in Croatia}

By signing the Stabilization and Association Agreement (SAA) Croatia assumed the obligation to harmonize its legislation governing state aid with the regulations of the Treaty Establishing the European Community. Article 70 of the SAA clearly specifies the requirements Croatia has to satisfy (see Box 3 ), which are also defined in the Implementation Plan for SAA. According to the Ministry for European Integration, most measures have either been implemented or are in the process of implementation (see Table 3).

\section{Box 3. SAA Provisions Relevant for State Aid}

Title VI Article 70: "Competition and other economic provisions" of the SAA contains the following regulations governing state aid (we only cite the abstracts which are directly related to state aid):

1. "The following are incompatible with the proper functioning of the Agreement, in so far as they may affect trade between the Community and Croatia:

(iii) any state aid which distorts or threatens to distort competition by favoring certain undertakings or certain products.

2. Any practices contrary to this Article shall be assessed on the basis of criteria arising from the application of the competition rules applicable in the Community, in particular from Articles 81, 82, 86 and 87 of the Treaty establishing the European Community and interpretative instruments adopted by the Community institutions.

3. Croatia shall establish an operationally independent authority, which is entrusted with the powers necessary for the full application of paragraph 1 (iii) of this Article within one year from the date of entry into force of this Agreement. This authority shall have, inter alia, the powers to authorize state aid schemes and individual aid grants in conformity with paragraph 2 of this Article, as well s the powers to order the recovery of state aid that has been unlawfully granted.

4. Each Party shall ensure transparency in the area of state aid, inter alia, by providing to the other Party a regular annual report, or equivalent, following the methodology and the presentation of the community survey on state aid. Upon request by one Party, the other Party shall provide information on particular individual cases of public aid.

5. Croatia shall establish a comprehensive inventory of aid schemes instituted before the establishment of the authority preferred to in paragraph 4 and shall align such aid schemes with the criteria referred to in paragraph 2 of this Article within a period of no more than four years from the entry into force of this Agreement.

6. (a) For the purposes of applying the provisions of paragraph 1(iii), the Parties recognize that during the first four years after the entry into force of this Agreement, any public aid granted by Croatia shall be assessed taking into account the fact that Croatia shall be regarded as an area identical to those areas of the Community described in Article 87(3)(a) of the Treaty establishing the European Community.

(b) Within three years from the entry into force of this Agreement, Croatia shall submit to the Commission of the European Communities its GDP per capita figures harmonized at NUTS II level. The authority referred to in paragraph 4 and the Commission of the European Communities shall 


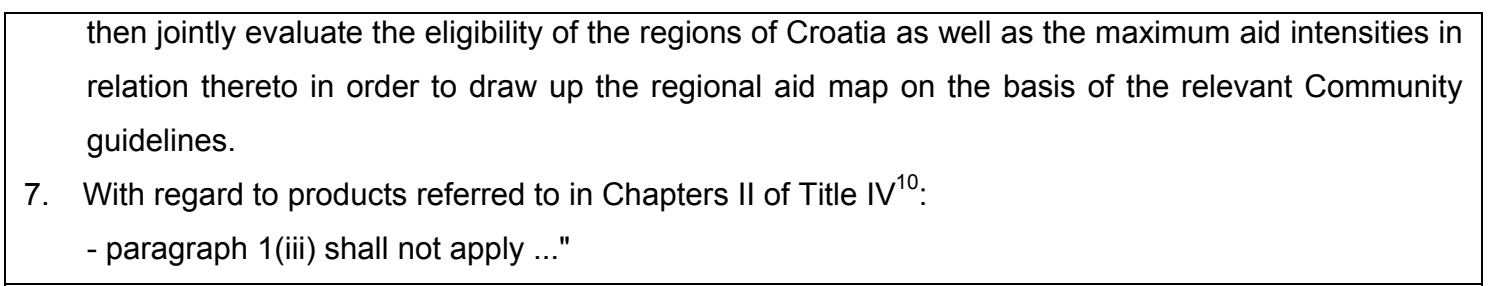

Table 3 Implementation of SAA Measures Related to State Aid

\begin{tabular}{|l|l|l|}
\hline Measure & Status & Note \\
\hline $\begin{array}{l}\text { Draft a report on state aid for } \\
2002\end{array}$ & Implemented & $\begin{array}{l}\text { The report on state aid for 2002 was drafted on the basis } \\
\text { of the current legal framework. The report will be } \\
\text { submitted to the representatives of the European } \\
\text { Commission. Upon entering into force of the State Aid } \\
\text { Act a new report will be drawn up on the basis of this Act. }\end{array}$ \\
\hline Draw up a Draft State Aid Act & Implemented & The State Aid Act was enacted in March 2003. \\
\hline $\begin{array}{l}\text { Establish an independent state } \\
\text { aid agency }\end{array}$ & Implemented & $\begin{array}{l}\text { Pursuant to the State Aid Act, the Agency for the } \\
\text { Protection of Market Competition (APMC) became } \\
\text { responsible for the supervision and implementation of the } \\
\text { state aid system. }\end{array}$ \\
\hline $\begin{array}{l}\text { Draw up a list of all existing state } \\
\text { aid programs }\end{array}$ & Implemented & $\begin{array}{l}\text { List of all existing state aid programs has been adopted } \\
\text { and submitted to the Ministry for European Integration for } \\
\text { review. }\end{array}$ \\
\hline $\begin{array}{l}\text { Conduct an analysis of the degree } \\
\text { of compatibility between Croatian } \\
\text { legislation with the acquis. }\end{array}$ & Implemented \\
\hline $\begin{array}{l}\text { Draw up a timetable for the } \\
\text { harmonizing the current state aid } \\
\text { programmes with the criteria } \\
\text { specified in Article 70(2) and (6). }\end{array}$ & $\begin{array}{l}\text { The Analysis is completed and has been submitted to the } \\
\text { Ministry for European Integration for review. }\end{array}$ \\
\hline
\end{tabular}

Source: Ministry for European Integration, 2003.

The State Aid Act was enacted in March $2003^{11}$. The provisions of the Act are very similar to the regulations of the Treaty Establishing the European Community, which is not surprising, given that the entire Croatian legislation must be harmonized with the acquis.

By virtue of the Act, the Agency for the Protection of Market Competition is entrusted with the powers to "to approve, supervise, implement and order the recovery of general and individual state aid" (Article 5). This represents a fulfillment in nominal terms of the requirement set by the SAA concerning the establishment of "an operationally independent authority" which is entrusted with the powers to monitor the implementation of the rules on state aid. However, according to the Commission, the APMC is not yet trained enough to perform these tasks in an appropriate way (for more detail see Box 4). It is evident that the Croatian state administration still has to make much effort in order to implement the measures agreed under the SAA.

\footnotetext{
${ }^{10}$ This relates to agriculture and fisheries.

11 The Act was published in the official gazette Narodne novine, No. 47 of 25 March 2003. The Decree on State Aid was published in the official gazette Narodne novine, No. 121 of 29 July 2003.
} 


\section{Box 4. What Does the Commission of the European Communities Think About the Croatian State} Aid?

"The need to adopt a new competition act and the necessary legislation regulating mergers was identified as a priority in the previous report. Increasing the administrative capacity of the Agency for the Protection of Market Competition including a substantial increase in its staff. Adopting a legislative framework for state aid and establishing an independent authority responsible for their control. In 2002, Croatia started an important preparatory work but none of these priorities have been fully implemented yet.

The Agency for the Protection of Market Competition is not fully functional and experiences problems to absorb the intended assistance. Some positive steps have been taken in the 2003 budget, which provided for a significant increase in the staff of the Agency (currently 17 employees) allowing the recruitment of 4 lawyers and 4 economists. Government support for certain training activities will also be increased.

Under the Interim Agreement Croatia assumed the obligation to establish an operationally independent state aid authority by 1 March 2003 and to provide a regular annual report on state aid. Croatia did not respect this deadline, as the State Aid Act establishing inter alia the mandate and responsibilities of the State Aid Agency is still in the final stage of the legislative procedure ${ }^{12}$. The Ministry of Finance is still working on an inventory of state aid*. The completion of this work and the establishment of the annual report on state aid should be pursued as a matter of priority. In general, the presence of state aid in economic transactions is still very high and takes the form of implicit subsidies, sponsored contracts or guarantees."

*According to the information provided by the Ministry for European Integration, in the meantime the inventory has been established (see Table 3).

Source: Commission of the European Communities, 2003 (Chapter 4.2.5. Competition and State Aid).

\section{State Aid in Croatia}

\subsection{Methodology for Measurement of State Aid in the European Union}

Although it is difficult to collect comprehensive data on state aid, it is worth noting that other sources, besides the European Commission, provide data on government aid to enterprises, e.g. System of National Accounts (SNA), World Trade Organization or OECD (see Box 5). However, it is very difficult to make comparison between the data published from the stated sources, given the difference in the definitions and scope used in each case. Thus, for example, the term 'industry' sometimes relates to manufacturing and sometimes it includes both manufacturing and services. Another difference relates to instruments used: sometimes they only represent grants from the state budget, while in other cases they include several instruments: tax exemptions, soft loans, etc. Therefore, when comparing the data from various sources it needs to be clearly specified what these data actually imply.

\section{Box 5. International Sources of Data on State Aid}

Apart from the European Commission, which regularly publishes figures on state aid in Member States, such data are also published within the SNA, as well as by the WTO and OECD.

Within the System of National Accounts (SNA) the term 'grant' only includes direct transfers to

\footnotetext{
$\overline{12}$ In the meantime the Act has been enacted. See footnote 11.
} 
enterprises from the budget, excluding other forms of assistance like subsidized loans, tax exemptions, etc.

The World Trade Organization (WTO) is another source of data on state aid. It is based on the obligation to notify subsidies, which include direct transfers of funds, fiscal incentives and government supply of goods and services (excluding general infrastructure). However, these data are often incomplete, owing to the difficulties in data collection and notification of grants in certain countries.

OECD publishes annual data on subsidies to industry for 25 Member States. These data include budget transfers, soft loans, inputs purchased at prices lower than the market prices and tax revenue losses. However, these data only relate to aid for industry.

Source: Lee, 2002.

Ever since 1988, the European Commission has published regularly the Surveys on State Aid in the European Union. The first survey covered the period 1981-1986 and the next surveys followed at regular 2-year intervals. However, in order to increase the transparency of data on state aid and to provide up-todate figures the European Commission decided to publish surveys annually instead of on a biannual basis as from 1998 (Commission of the EC, 2001:12). A total of 9 Surveys on State Aid were published. As from July 2001, the European Commission has published State Aid Scoreboards. The Scoreboard, much shorter than the Survey, presents clear and simple information on state aid as well as on the current activities of the Commission in this area. The EU constantly improves the information on State aid, which contributes to the transparency of the system. Therefore, the Scoreboard is published twice in a year: in spring and autumn. Besides the hard copy edition, a part of the Scoreboard, which is regularly updated, is available on the EU website at: <http://europa.eu.int/comm/competition/state_aid/scoreboard/>. In order to improve the transparency of the state aid system, the EU website also includes a complete register of the Commission's decisions concerning state aid <http://europa.eu.int/comm/competition/state_aid/register/>.

Here we present the methodology for collecting data on and measurement of state aid, which is also used to prepare the State Aid Scoreboard. This methodology has not been published separately but has been included in a number of guidelines, instructions and decisions issued by the European Commission and the EC Court of Justice. Its basic elements are outlined in "Competition State Aid Scoreboard Conceptual and methodological remarks" (European Commission, 2003). We used this same methodology for collecting the data on state aid in Croatia, presented in the next section. This chapter also explains what is and what is not considered as state aid, for which purposes and through which instruments is aid provided and specifies the methods of assessing the aid element in individual categories of aid.

\subsubsection{What Constitutes State Aid?}

